\title{
Resuscitating The Dormant Accounting Scholar
}

\author{
Kimberly Gladden Burke, Millsaps College, USA \\ Susan Washburn Taylor, Millsaps College, USA \\ Blakely Fox Fender, Millsaps College, USA
}

\begin{abstract}
Despite the fundamental importance of publication to the academic institution, there are a significant number of dormant accounting scholars who simply do not publish. Building upon an existing literature on the determinants of academic productivity, this paper identifies factors which have the potential to revive scholarly productivity. Specifically, the current research reinforces the positive impact of scholarly presentations, sabbatical leave, and teaching assistants on reviving the dormant scholar. Similarly, reducing activities which compete for the academic's time (teaching undergraduate courses, consulting, and service to the institution) will increase the odds of publication.
\end{abstract}

Keywords: Opportunity costs, academic productivity, scholarly productivity, dormant scholar

\section{INTRODUCTION}

$\mathcal{O}$ ne of the central goals of "the University" is the production and dissemination of knowledge by a community of active scholars. This goal is supported by doctoral programs that emphasize the production of publishable research and reinforced by accrediting bodies such as AACSB International (2008) which require the production of intellectual contributions. In business schools, the gold standard for disseminating knowledge is most often publication in peer-reviewed journals. Promise of such publication typically constitutes an important driver to decisions involving the hiring of accounting faculty, and fulfillment of that promise generally informs retention, tenure and promotion decisions as well as salary decisions.

Despite the fundamental importance of publication to the scholarly model, there are a significant number of dormant accounting scholars, i.e. those who simply do not publish (Zivney et al. 1995; Demski and Zimmerman 2000). In their analysis of faculty publishing in the top 40 journals from 1967 through 2001, Hasselback et al. (2003) find that roughly 50\% of accounting faculty published no articles, and more than $70 \%$ wrote 2 or fewer articles. Chung et al. (1992) confirm that a large percentage of publications are authored by a disproportionately few accounting faculty. In addition, dormant scholars are more common in accounting than in other disciplines including finance, management and marketing (Swanson 2004).

While significant literature exists across many disciplines that examines research productivity, including which scholars publish most, the quality of where they publish, which doctoral programs graduate the scholars who publish most, etc.(see for example, Cargile and Bublitz 1986; Hasselback and Reinstein 1995; Hasselback et al. 2003; Burke et al. 2003), extant research has not focused on models examining the dormant scholar. Accordingly, using a logit analysis of responses obtained from 468 accountants at academic institutions, this study analyzes variables influencing the probability that the dormant scholar will publish. The study models the probability of publishing as a function of a number of "manageable" variables, those controlled by the dormant scholar and his or her institution, as well as other control variables found in prior research to be important determinants of productivity. 


\section{THE STUDY}

A web-based survey was conducted to collect information about accountants. An e-mail was sent to accountants at American colleges and universities in May, 2004, inviting them to go to a secure web page which posted the survey. E-mail addresses were obtained from Hasselback (2002). While this guide omits some accountants, there is no reason to suspect systematic omission. Approximately $26 \%$ of the original e-mails were returned as undeliverable, yielding a population of 4,190 . The survey provided a $\$ 10$ charitable donation as an incentive to respond.

Questionnaires were completed by 600 accountants yielding a participation rate of $14.3 \%$. Of the 600 responses received, a number of them were excluded from the study. Approximately 75 responses did not include adequate information to link the individual to his or her publishing information. Additional observations were dropped if they represented individuals with unusually heavy administrative burdens (e.g., university presidents, directors of research centers). Finally, persons with two years experience or less were omitted. These individuals have had little time to push research through the pipeline, making it difficult to identify them as either active or dormant scholars. Finally, persons classified as instructors were omitted. Ultimately, 468 usable responses were available for analysis.

The survey asked for a variety of information related to accountants' human capital and workplace characteristics, including the respondent's name. Many of the time-varying characteristics were limited to the 5 year period from 1998 through 2002. For example, questions about research support and service were couched in terms of the most recent 5 year period. While this time period is somewhat arbitrary, it is a sufficient period to reflect conditions over time without being so long as to make recall difficult and thus reduce the survey response rate. It is also in keeping with AACSB International Standards (2008) of review for publication. The explanatory variables available from the survey are listed in the Appendix.

\section{Research Productivity}

Research productivity is a dichotomous dependent variable that equals 1 if the respondent had any publications in the five-year-period under review (active scholar), 0 otherwise (dormant scholar). Refereed journal articles are commonly accepted as the primary outlet for scholarly research in the field. Accordingly, information regarding peer-reviewed journal articles (including notes, but excluding comments and replies) for each respondent from 1998-2002 was gathered from three databases, EconLit, Ingenta, and EBSCO Host.

Examinations of research productivity often adjust the number of articles for journal quality and coauthorship, both of which are excluded from this study. Adjustments for journal quality may be useful in distinguishing the scholarly excellence of articles among active scholars. When focusing on reviving the dormant scholar, however, the primary goal is publication in a peer-reviewed journal; quality becomes secondary. Similarly, issues related to whether authors receive full or partial credit for co-authored articles are significantly less important to the dormant scholar than they perhaps are to the active scholar.

\section{Manageable Variables}

There are a number of variables which can be controlled by the dormant scholar and his or her institution that may significantly affect the probability of publishing. These include presentations at professional conferences, consulting, service to the department or institution, teaching loads, and financial support for research activity.

Dormant scholars may enhance their research productivity by actively participating in presentations of their work at professional conferences. Burke et al. (2008) provide empirical evidence of positive impact of presentations on publication. These presentations are assumed to positively impact the probability of publication for a variety of reasons. First, the process of preparing a presentation is similar to the process of preparing a paper for submission. Second, the act of presenting often results in useful pre-submission feedback from peers, improving the paper's chances of publication. And, third, presentations impose a deadline for the completion of a manuscript, the kind of deadline that generally does not exist for submitting a paper for publication. As a result, presentations are expected to increase the probability of publication. 
Some academic accountants may also engage in activities that cater to the more practical nature of accounting rather than their scholarly efforts, such as consulting. Little research exists to indicate the effect of consulting on research productivity. Based on their survey of deans and management professors, Kondrasuk et al. (1979) argue that consulting appears to improve both teaching and research, although teaching is more improved by consulting than is research. The prevailing anecdotal argument, however, as noted by Sennetti (1981) and Boyle (2008) suggests that while consulting offers academics opportunities to supplement their incomes, it competes for the academic's time, most notably the time to conduct research. Accordingly, consulting activities are assumed to negatively impact the probability of publication.

One commonly cited research detractor is service to the department or institution. While it is intuitively appealing that such service would reduce the probability of publication, Burke et al. (2008) provide some empirical support for this claim in their examination of accountants publishing in top ten journals. Their results report the negative impact of committee and department chair service on research productivity. As a result, research productivity and service to the department or institution are expected to negatively impact the probability of publication.

Academic institutions have a variety of resources at their disposal that may be useful in supporting research activity and reviving the dormant scholar. Graduate assistants are useful to researchers, particularly in collecting and organizing data. Similarly, large quantities of time devoted specifically to conducting research, such as in the form of a sabbatical, also are more likely to increase the probability of active scholarship.

Workload effects are also important when contemplating the resuscitation of a dormant scholar. While the exact nature of the relation between teaching load and research productivity has long been debated (Demski and Zimmerman 2000), several researchers (Manakyan and Tanner 1994; Cargile and Bublitz 1996; Burke et al. 2008) confirm that teaching and research activities are substitutes for one another in the short run, such that time engaged in one activity cannot be used for the other. All teaching commitments may not necessarily be the same, though. Discussions in a master's or doctoral level class may create some synergy with research productivity, prompting lines of scholarly inquiry or providing eager coauthors. So, while teaching load is expected to negatively impact the probability of research productivity, this model separately examines the effects of undergraduate, graduate and summer teaching loads.

\section{Control Variables}

Prior research has identified a number of variables that are important determinants of research productivity, but which cannot reasonably be altered by the dormant scholar or his or her institution once the scholar has become dormant, if at all. These variables are included herein as control variables and include gender, quality of doctoral program, years to completion of the Ph.D., and AACSB accreditation status.

The literature examining gender impact on research productivity is mixed. Consistent with numerous articles in other fields (Maske et al., 2003; Broder, 1993 and Rebne and Davidson, 1992) that report women publish less than men, Dwyer (1994) finds that female accountants publish significantly fewer articles than their male counterparts. Streuly and Maranto (1994) and Burke et al. (2008), however, find no significant differences between the research productivity of male and female accountants. Similarly, Fogarty (2004) demonstrates no significant difference between the sustained research productivity of senior males and females in accounting. Due to the conflicting nature of the extant literature on gender, we include gender in this model, but do not have an a priori expectation regarding its influence on the probability of publication.

A significant body of research indicates that the quality of the doctoral program from which one graduates influences subsequent research productivity. Maranto and Streuly (1994), Fogarty and Ruhl (1997) and Burke et al. (2008) find that those who earn degrees from higher status doctoral programs tend to be more productive. Chung et al. (1992) noted that approximately one-third of the particularly prolific scholars were graduates of seven high quality programs. Fogarty's (2004) study of the senior cohort indicates the sustainability effect of the quality of the 
Ph.D. program. Accordingly, we expect the quality of the doctoral program to significantly influence the probability of research productivity. ${ }^{1}$

Others factors may reflect individual motivation and opportunity to succeed in the field. For example, reasoning that those who are less aggressive in pursuing the doctoral degree will be less productive, Burke et al. (2008) find that the number of years required to complete the Ph.D. has a significant negative relation to future productivity. Similarly, Hasselback et al. (2003) note that the number of years since earning the doctoral degree should be indicative of research productivity, given that more recent graduates have had less time to publish.

Finally, the institution's accreditation is expected to positively impact the probability of publication. AACSB International requires the mission statement of an accredited business school to include the "production of intellectual contributions that advance the knowledge and practice of business management (AACSB International, p.13)." As a result, those employed by an accredited business school are much more likely to be active, rather than dormant, scholars.

\section{RESULTS}

\section{Descriptive Data}

Table 1 provides the summary statistics for the dormant and active scholars. On average, dormant scholars make significantly fewer presentations (0.98) per year than do the active scholars (1.61) per year. In addition, a higher percentage (37\%) of dormant scholars engages in consulting activities, compared to only $22 \%$ of the active scholars. With regard to committee service, there is no significant difference between the amount of service provided by dormant and active scholars. There is, however, a significantly larger percentage of dormant scholars who serve as department chairs. On average, dormant scholars served 1.37 years as department chair, compared to active scholars who served 0.88 years as department chair.

In terms of resources available to support scholarship, the descriptive statistics show mixed results. Dormant scholars have access to significantly fewer semesters of graduate assistant support, 1.43 semesters on average versus 3.81 semesters for the active researchers. Both active and dormant scholars enjoy approximately the same amount of sabbatical support.

Workload assignments show some significant differences. On the whole, the active scholars teach fewer undergraduate courses ( 9.21 per year) and more graduate courses (4.79 per year) than the dormant scholars (14.17 and 3.02 per year, respectively). Both active and dormant scholars report similar amounts of summer teaching.

With regard to the control variables, roughly $75 \%$ of the respondents were male, with no significant differences between active and dormant scholars. It is perhaps not surprising that active scholars tend to have received their Ph.Ds from higher quality programs (.17 versus .12 quality rating) and to have taken almost one year less on average ( 4.76 years for active scholars versus 5.57 years for dormant scholars) to complete their doctoral program. Interestingly, dormant scholars have significantly more experience (17.65 years) than do their active counterparts (15.59 years). About $88 \%$ of the active scholars are employed by an accredited business school compared to $58 \%$ of the dormant scholars.

\footnotetext{
${ }^{1}$ Rankings obtained from Hasselback and Reinstein (1995) were used to represent the quality of the doctoral school for each respondent. These rankings are based on the number of articles and quality of those articles produced by each school's faculty and adjusted for differing faculty size.
} 
Table 1 -- Differences of Means (Standard Deviations in Parentheses)

\begin{tabular}{|c|c|c|c|c|}
\hline & full sample & no pubs & pubs & significance \\
\hline $\begin{array}{c}\text { Manageable Variables } \\
\text { presentations }\end{array}$ & $\begin{array}{l}1.35 \\
(1.35)\end{array}$ & $\begin{array}{c}0.98 \\
(0.99)\end{array}$ & $\begin{array}{c}1.61 \\
(1.49)\end{array}$ & $* *$ \\
\hline consulting & $\begin{array}{c}0.28 \\
(0.45)\end{array}$ & $\begin{array}{c}0.37 \\
(0.48)\end{array}$ & $\begin{array}{c}0.22 \\
(0.41)\end{array}$ & $* *$ \\
\hline committees & $\begin{array}{c}3.56 \\
(1.94)\end{array}$ & $\begin{array}{c}3.42 \\
(1.75)\end{array}$ & $\begin{array}{c}3.66 \\
(2.05)\end{array}$ & \\
\hline department chair & $\begin{array}{l}1.08 \\
(1.73)\end{array}$ & $\begin{array}{c}1.37 \\
(1.90)\end{array}$ & $\begin{array}{c}0.88 \\
(1.59)\end{array}$ & ** \\
\hline graduate assistant & $\begin{array}{c}2.85 \\
(3.72)\end{array}$ & $\begin{array}{l}1.43 \\
(2.78)\end{array}$ & $\begin{array}{c}3.81 \\
(3.97)\end{array}$ & ** \\
\hline sabbatical & $\begin{array}{c}0.25 \\
(0.52)\end{array}$ & $\begin{array}{c}0.21 \\
(0.46)\end{array}$ & $\begin{array}{c}0.28 \\
(0.56)\end{array}$ & \\
\hline undergraduate teaching load & $\begin{array}{l}11.22 \\
(7.71)\end{array}$ & $\begin{array}{l}14.17 \\
(7.86)\end{array}$ & $\begin{array}{c}9.21 \\
(6.94)\end{array}$ & $* *$ \\
\hline graduate teaching load & $\begin{array}{c}4.07 \\
(4.38)\end{array}$ & $\begin{array}{c}3.02 \\
(3.83)\end{array}$ & $\begin{array}{c}4.79 \\
(4.59)\end{array}$ & ** \\
\hline summer teaching load & $\begin{array}{c}2.23 \\
(2.66)\end{array}$ & $\begin{array}{c}2.31 \\
(2.78)\end{array}$ & $\begin{array}{c}2.18 \\
(2.58)\end{array}$ & \\
\hline $\begin{array}{l}\text { Control Variables } \\
\quad \text { gender }(\text { male }=1)\end{array}$ & $\begin{array}{c}0.74 \\
(0.44)\end{array}$ & $\begin{array}{c}0.77 \\
(0.42)\end{array}$ & $\begin{array}{c}0.71 \\
(0.45)\end{array}$ & \\
\hline Ph.D. quality & $\begin{array}{c}0.15 \\
(0.12)\end{array}$ & $\begin{array}{c}0.12 \\
(0.11)\end{array}$ & $\begin{array}{c}0.17 \\
(0.12)\end{array}$ & ** \\
\hline years to $\mathrm{Ph} . \mathrm{D}$. & $\begin{array}{c}4.17 \\
(2.61)\end{array}$ & $\begin{array}{c}5.57 \\
(2.18)\end{array}$ & $\begin{array}{c}4.76 \\
(1.76)\end{array}$ & ** \\
\hline experience & $\begin{array}{l}16.43 \\
(8.98)\end{array}$ & $\begin{array}{l}17.65 \\
(9.58)\end{array}$ & $\begin{array}{l}15.59 \\
(8.47)\end{array}$ & $* *$ \\
\hline AACSB accreditation & $\begin{array}{c}0.76 \\
(0.43)\end{array}$ & $\begin{array}{c}0.58 \\
(0.50)\end{array}$ & $\begin{array}{c}0.88 \\
(0.32)\end{array}$ & ** \\
\hline Number of Observations & 468 & 190 & 278 & \\
\hline
\end{tabular}


Table 2 -- Logit Estimates

Dependent Variable $=1$ if Accountant Published in the Five Years Under Review (Z-Statistics Reported in Parentheses)

Manageable Variables presentations

consulting

committees

department chair

graduate assistant

sabbatical

undergraduate teaching load

graduate teaching load

summer teaching load

Control Variables

gender $($ male $=1)$

Ph.D. quality

years to $\mathrm{Ph} . \mathrm{D}$.

experience

experience squared

AACSB accreditation

Pseudo R-Squared

Number of Observations

\begin{tabular}{|c|c|c|}
\hline coefficient & odds ratio & z-statistic \\
\hline $0.30 * *$ & 1.34 & 2.86 \\
\hline$-0.40 *$ & 0.67 & -1.52 \\
\hline 0.02 & 1.02 & 0.31 \\
\hline$-0.14 * *$ & 0.87 & -2.06 \\
\hline $0.11 * *$ & 1.12 & 3.25 \\
\hline $0.29 *$ & 1.34 & 1.28 \\
\hline$-0.04 * *$ & 0.97 & -1.83 \\
\hline 0.02 & 1.02 & 0.65 \\
\hline 0.03 & 1.03 & 0.64 \\
\hline
\end{tabular}

$-0.26$

0.77

$-0.99$

$1.89 * *$

6.64

1.74

$-0.09 * *$

0.92

$-1.88$

$0.10 * *$

1.10

1.87

$0.00 * *$

1.00

$-2.60$

$1.03 * *$

2.81

3.51
0.21

468.00

* indicates statistical significance at the 10 percent level.

** indicates statistical significance at the 5 percent level.

\section{Logit Results}

While the t-tests of the previous section indicate a significant difference of means across dormant and active scholars, multivariate techniques are necessary to show the impact of the variables on the probability of publishing. Thus, logit analysis is used to estimate the probability of publication as a function of each of the manageable and control variables. Results of the analysis are presented in Table 2. Coefficients in the logit analysis do not have a straightforward interpretation. Accordingly, we have calculated the odds ratio for each of the 
independent variables. $^{2}$ This ratio should be compared to a value of 1; whereas, an OLS regression coefficient is compared to a baseline of 0 . Odds greater than 1 indicate that the regressor under examination has a positive impact on publication and odds less than 1 indicate that the regressor has a negative impact on publication.

Moreover, the odds ratio has a useful interpretation. Consider, for example, the odds ratio of 1.34 for the regressor Presentations, reflecting the number of presentations a scholar gives in a typical year. This ratio indicates that the scholar who presents one additional paper per year is 1.34 times as likely to publish as the scholar who does not present an additional paper, ceteris paribus. Another way of stating this result is that the addition of one presentation (in the five year period under review) results in a 34 percent increase in the likelihood of publication. On the other hand, taking an additional year to complete the Ph.D. program decreases the probability of publishing by 8 percent.

Most results are as anticipated. Additional presentations increase the likelihood of publication (34\%), while additional consulting decreases that likelihood (33\%). Interestingly, committee work has no significant effect on the probability of publishing, but acting as department head reduces the probability of publication by about $13 \%$. Adding resources to support research, including graduate assistants and sabbaticals, increase the probability of publication by $12 \%$ and $34 \%$, respectively.

Findings related to teaching are mixed. Certainly, increasing the number of undergraduate hours taught by one hour results in a $3 \%$ reduction in the probability of publication (this equates to roughly a $6 \%$ decrease in probability for an adding a 3-hour course). What is most interesting, however, is that neither graduate nor summer hours significantly influence the probability of research productivity. The lack of relation between graduate hours and productivity may suggest an interesting trade-off. Obviously, any additional teaching takes time away from research activities, but the interactions with graduate students and the nature of the classes may, in fact, provide research ideas or prompt a research interest that offsets the time commitment.

In general, findings related to control variables are as expected. Ph.D. quality, years to Ph.D. experience, and AACSB accreditation are significantly related to the probability of publication. Only gender had no significant influence.

\section{DISCUSSION}

Certainly, the preceding analysis confirms that scholars are more likely to be active if they have obtained their Ph.D. more quickly from a higher quality institution and have significant experience. That stated, however, the more substantive findings of the model are that there are meaningful ways to encourage and support dormant scholars as they become active.

There are obviously several reasons why a scholar may be dormant. The academic may be young and not yet have had time to push research through the system. Faculty in the mid to latter years who have not published may have simply given up. Similarly, institutions place differing values on scholarly productivity. Those with limited resources may be less willing to commit those resources to a dormant scholar. For those individuals and institutions, however, who view scholarship as fundamental to the life of the academic institution, this research provides some meaningful suggestions for reviving the dormant scholar.

The results of this study demonstrate that the resuscitating the dormant scholar requires action by both the scholar and the institution. First, the institution must encourage the dormant scholar to change his or her work patterns. The current research indicates that dormant scholars must be convinced to commit their time to their scholarship, perhaps foregoing more lucrative consulting arrangements which compete for the academic's time. In addition, as part of annual goal setting, the dormant academic should be encouraged to take an intermediary step to publication by setting firm expectations to present his or her work at academic conferences.

\footnotetext{
${ }^{2}$ The odds ratio is found by taking the exponent or the antilogarithm of the logit coefficient.
} 
Second, institutions must consider the resources made available to the dormant scholar to encourage scholarly activity. Both the provision of a graduate assistant and sabbaticals to conduct research are relatively low cost measures that can be provided to dormant scholars. While some institutions may not be willing to chance a sabbatical on a non-producing member of the faculty, by using the annual review and goal-setting process the institution can offer the sabbatical as an incentive once the dormant scholar has shown progress toward becoming active.

Finally, institutions should consider the degree to which the dormant scholar is teaching undergraduate hours. Our findings indicate that the opportunity to teach fewer undergraduate hours in exchange for increased scholarship may be an attractive offer for the dormant scholar seeking to publish.

While the reasons for the large number of dormant scholars in accounting remain a mystery, the results of this study provide valuable insight regarding factors that increase the probability of publication. Specifically, the current research emphasizes the positive relation between scholarly presentations, sabbatical leave, and teaching assistants and the probability of achieving the gold standard, i.e. publishing in peer-reviewed journals. Similarly, reducing activities which compete for the academic's time (teaching undergraduate courses, consulting, and service to the institution) will increase the odds of publishing. In order to maintain the scholarly model underlying most academic departments and to comply with accreditation standards, accountants must focus on resuscitating the dormant scholar.

\section{AUTHOR INFORMATION}

Kimberly Gladden Burke is Professor of Accounting and the Cook Chair of Business Administration at Millsaps College in Jackson, MS. She received her Ph.D. in accounting at Oklahoma State University.

Susan Washburn Taylor is Professor of Economics and McRae Chair of Business Administration at Millsaps College. She received her Ph.D. in economics at Louisiana State University.

Blakely Fox Fender is Associate Professor of Economics and Brown Chair of Business Administration at Millsaps College. She received her Ph.D. in economics at the University of Texas, Austin.

\section{REFERENCES}

1. AACSB International. 2008. Eligibility Procedures and Accreditation Standards for Business Accreditation. (Tampa, FL: AACSB International).

2. Broder, I.E. 1993. Professional Achievements and Gender Differences Among American Accountants. Economic Inquiry (Vol. 31) 116-27.

3. Boyle, G. 2008. Academic Salaries: Where Angels Fear to Tread. Chartered Accountants Journal (Vol. 87, No. 1) 30-32.

4. Burke, K.B., B.F. Fender and S.W. Taylor. 2008. Swinging for the Fences: Human Capital and Workplace Characteristics of Accountants Publishing in Top Journals. The Accounting Educators' Journal (Vol. 18) 29-46.

5. Cargile, B.R. and B. Bublitz. 1986. Factors Contributing to Published Research by Accounting Faculties. The Accounting Review (Vol. 61, No. 1) 158-178.

6. Chung, K.H., H.S. Pak, and R.A.K. Cox. 1992. Patterns of Research Output in the Accounting Literature: A Study of Bibliometric Distributions. ABACUS (Vol. 28, No. 2) 168-185.

7. Demski, J.S. and J.L. Zimmerman. 2000. On 'Research vs. Teaching': A Long-Term Perspective. Accounting Horizons (Vol. 14, No. 3) 343-352.

8. Dwyer, P.D.1994.Gender Differences in the Scholarly Activities of Accounting Academics: An Empirical Investigation. Issues in Accounting Education (Vol. 9, No. 2) 231-246.

9. Fogarty, T.J. 2004. Sustained Research Productivity in Accounting: A Study of the Senior Cohort. Global Perspectives on Accounting Education (Vol. 1) 31-58.

10. Fogarty T.J. and J.M. Ruhl. 1997. Institutional Antecedents of Accounting Faculty Research Productivity: A LISREL Study of the 'Best and Brightest. Issues in Accounting Education (Vol. 12, No.1) 27-48. 
11. Hasselback, J.R. 2002. Prentice Hall Accounting Faculty Directory 2002-2003. Prentice Hall.

12. Hasselback, J.R. and A. Reinstein. 1995. A Proposal for Measuring the Scholarly Productivity of Accounting Faculty. Issues in Accounting Education (Vol.10, No.2) 269-306.

13. Hasselback, J.R., A. Reinstein and E.S. Schwan. 2003. Prolific Authors of Accounting Literature. Advances in Accounting (Vol. 20) 95-125.

14. Kondrasuk J.N., C.Chandanasiri, J. Fuchs, L. Harris, L. Nye and B. Virangkura. 1979. The Perceived Relationship of Professors' Outside Management Consulting to Their Teaching and/or Research Effectiveness. Academy of Management Proceedings 145-149.

15. Manakyan, H. and J.R. Tanner. 1994. Research Productivity and Teaching Effectiveness: Accounting Faculty Perspective. Accounting Educators' Journal (Vol. 6, No.2) 1-21.

16. Maranto, C.L. and C.A. Streuly. 1994. The Determinants of Accounting Professors' Publishing Productivity - The Early Career. Contemporary Accounting Research (Vol.10, No.2) 387-407.

17. Maske, K.L., G.C. Durden, and P.E. Gaynor. 2003. Determinants of Scholarly Productivity Among Male and Female Accountants. Economic Inquiry (Vol. 41) 555-564.

18. Rebne, D.S. and N.B. Davidson. 1992. Understanding Patterns of Publishing Activity in Academic Research Occupations. Decisions Sciences (Vol. 23, No. 4) 944-956.

19. Senetti, J.T. 1981. The Academician's Choice: Compose or Consult? Interfaces (Vol. 11, No. 2) 38-41.

20. Streuly, C.A. and C.L. Maranto. 1994. Accounting Faculty Research Productivity and Citations: Are There Gender Differences? Issues in Accounting Education (Vol. 9, No.2) 247-258.

21. Swanson, E.P. 2004. Publishing in the Majors: A Comparison of Accounting, Finance, Management and Marketing. Contemporary Accounting Research (Vol. 21, No. 1) 223-255.

22. Zivney, T.L., W.J. Bertin and T.A. Gavin. 1995. A Comprehensive Examination of Accounting Faculty Publishing. Issues in Accounting Education (Vol. 10, No.1) 1-25. 


\section{Appendix \\ Variable Definitions}

\section{Manageable Variables \\ presentations}

consulting

committees

department chair

graduate assistant

sabbatical

undergraduate teaching load

graduate teaching load

summer teaching load

\section{Control Variables}

gender $($ male $=1)$

Ph.D. quality

years to Ph.D.

experience

AACSB accreditation
The average number of presentations made at professional conferences per year.

A dummy variable equal to 1 if the individual reports routinely providing consulting services.

The number of committees on which a person serves in a typical year.

The number of years serving as department chair in the timeframe under review.

Number of semesters the individual received a graduate assistant in the timeframe under review.

Number of semesters the individual received a sabbatical in the timeframe under review.

The number of undergraduate credit hours taught during an academic year.

The number of graduate credit hours taught during an academic year.

The average number of summer hours taught during a typical year.

A dummy variable equal to 1 for males and 0 for females.

Articles per graduate weighted by coauthorship and journal ranking taken from Hasselback and Reinstein (1995).

The number of years taken to complete the doctoral program.

The number of years since completion of the Ph.D.

A dummy variable equal to 1 if the individual's institution has AACSB accreditation. 